\title{
Efficacy of Lipase-Producing, Wax-degrading Bacteria against the Solenopsis Mealybug, Phenacoccus solenopsis Tinsley and the Striped Mealybug, Ferrisia virgata Cockerell (Homoptera: Pseudococcidae) on Cotton
}

\author{
Nagarathinam Arunkumar*, Jainullabudeen Gulsar Banu, \\ Nagarajan Gopalakrishnan and Arkalgud Hiriyannaiah Prakash \\ ICAR - Central Institute for Cotton Research (CICR), Coimbatore, Tamil Nadu and \\ Central University of Tamil Nadu, Thiruvarur, Tamil Nadu, India.
}

\begin{abstract}
A B S T RA C T
Lipases (EC 3.1.1.3) are triacylglycerol acylhydrolases that hydrolyze triglycerides to glycerol and fatty acids. The numerous applications of lipases in chemical, food, pharmaceutical, biotechnological, detergents and surfactants, and agricultural industries and in waste treatment plants proved their importance. In this study, 23 wax-degrading bacterial strains isolated from four mealybug species infesting cotton were screened for lipase production. On the basis of the 16S rRNA gene sequences, lipase-positive strains were classified into six genera, namely, Pseudoxanthomonas, Acinetobacter, Klebsiella, Providencia, Enterobacter, and Serratia. Acinetobacter lwoffii PSAD2 and A. beijerinckii PSAD7 isolates showed the maximum lipase production of $2.3 \mathrm{U} / \mathrm{mL}$ and $1.7 \mathrm{U} / \mathrm{mL}$, respectively, in the quantification process. In addition, the growth curve analysis confirmed that lipase production is associated with the growth phase of the isolates. The efficacy of the lipase producing wax degrading bacterial isolates was tested against the nymphs and adults of Solenopsis Mealybug, Phenacoccus solenopsis Tinsley and the Striped Mealybug, Ferrisia virgata Cockerell infesting cotton. The results clearly indicated that the bacterial isolates A. lwoffii PSAD2 and A. beijerinckii PSAD7 expressed maximum mortality percentage against the mealybugs. The results of this study will be helpful in developing lipase-based microbial insecticides for the management of waxy cuticle-protected insect pests.
\end{abstract}

Article Information
Received 07 November 2019
Revised 01 May 2020
Accepted 19 June 2020
Available online 26 January 2021
(early access)
Published 16 November 2021
Authors' Contribution
NA performed the experiments,
analyzed the data and wrote the paper.
JGB supervised the work. NG and
AHP critically reviewed the article.
Key words
Lipase, Wax, Bacteria, 16S rRNA,
Mealybug, Mortality

\section{INTRODUCTION}

$\mathrm{W}$ ax (derived from Anglo-Saxon word weax), a type of lipid, is technically an ester of long-chain fatty acids with long-chain fatty alcohols (Jetter et al., 2006). The wax esters, sterol esters, fatty alcohols, diols, ketones, aliphatic aldehydes, beta-diketones, triacylglycerol, and other basic biochemical constituents of wax vary with their origin. Essentially, plant and insect waxes are made of wax esters, alkyl esters, fatty acids, long-chain alcohols, aldehydes, ketones, beta-diketones, hydroxy-beta-diketones, and triacylglycerols (Hansen et al., 1997; Gołębiowski et al., 2011); however, the combination and composition of wax vary greatly between plants and insects (Nguyen et al., 2014; Arunkumar et al., 2018). After serving their intended purpose mainly as a protective layer, wax residues from living organisms are degraded by a group

\footnotetext{
Corresponding author: arunkumarpdf2015@gmail.com 0030-9923/2022/0001-0077 \$ 9.00/0

Copyright 2022 Zoological Society of Pakistan
}

of opportunistic wax-degrading microorganisms present in the environment. Waxes are hydrolyzed by these microorganisms by pseudosolubilization, microbial surfactant production, or the secretion of extracellular microbial lipases (Roper, 2004).

Lipases are glycerol ester hydrolases produced by plants, animals, and microorganisms to hydrolyze lipids by acting on the carboxyl ester bonds of triglycerides that results in fatty acids and glycerol (Madeira et al., 2017). The production of extracellular microbial lipases using agricultural residues such as rice bran, sugarcane bagasse, and wheat bran, which makes them more economical, is relatively cheaper than that of to animal or plant lipases (Babu and Rao, 2007). Microbial lipases are widely used in the biodegradation of crude oil (Benelli and Rajasekar, 2017), detergents and surfactants industry, pharmaceutical and food industry, agricultural industry, and pulp and paper industry, as they are eco-friendly and zero toxic and leave no harmful residues after action (Rajan et al., 2011).

In the agricultural industry, apart from residue management, microbial lipases are used in insect pest 
control along with chitinase, protease, chitin deacetylase, beta-1,3-glucanase, and chitosanase. Mealybugs are regularly occurring sucking pests in most agriculture crops which render significant loss in the measure and standard of the economic produce. Mealybugs contain powdery waxy coating on the dorsal side to protect them from desiccation and penetration of toxic chemicals (Watson and Kubiriba, 2005), which also make their cadavers a suitable habitat for the isolation of complex hydrocarbon-degrading microorganisms. From the cadavers of Maconellicoccus hirsutus, the pink mealybug, three novel wax-degrading isolates identified as Bacillus subtilis, Pseudomonas aeruginosa, and Serratia marcescens were isolated by Salunkhe et al. (2013), with focus on eco-friendly mealybug management. Wax-protected insect cuticle is made easily accessible for degradation by chitinases and proteases after the action of lipase enzyme, which was confirmed by the laboratory bioassay of Ceratovacuna lanigera (sugarcane woolly aphid) with fungal and bacterial lipases (Chavan, 2009). Nonetheless entamopathogenic fungi (EPF) are widely used for the control of insect pests but due to their slow killing rates they have not been commercially successful and bacterial entomopathogens with relatively enhanced killing speed represent a very attractive alternative (Korany et al., 2019). Hence, this study aimed to screen, characterize and document the efficacy of lipaseproducing, wax-degrading bacteria (WDB) isolated from mealybugs for their possible applications as biocontrol agents in future.

\section{MATERIALS AND METHODS}

\section{Location and chemicals}

The experiments were performed at the Indian Council of Agricultural Research-Central Institute for Cotton Research, Regional Station, Coimbatore, Tamil Nadu, India during the year $2018\left(11.014327^{\circ} \mathrm{N}\right.$ latitude, $76.929456^{\circ} \mathrm{E}$ longitude). The analytical reagent grade chemicals were used for media preparation and biochemical studies (HiMedia, Mumbai, India).

\section{Isolation of wax-degrading bacteria from mealybug}

A total of 23 WDB isolates designated as PSAD (1 to 23) were previously isolated in the laboratory (Arunkumar et al., 2017) using modified Davis minimal agar medium containing mealybug wax $(2 \mathrm{~g} / \mathrm{L})$, ammonium sulfate $(1.0$ $\mathrm{g} / \mathrm{L})$, dipotassium phosphate $(7 \mathrm{~g} / \mathrm{L})$, magnesium sulfate $(0.1 \mathrm{~g} / \mathrm{L})$, and agar $(15 \mathrm{~g} / \mathrm{L})$ at $\mathrm{pH}$ 7. Mealybug cadavers of four mealybug species Ferrisia virgata Cockerell, Phenacoccus solenopsis Tinsley, Drosicha mangiferae Green and Paracoccus marginatus Williams and Granara de Willink, were separately immersed in the sterile saline solution $(0.8 \%)$ in $50 \mathrm{~mL}$ centrifuge tubes, followed by vortex for $5 \mathrm{~min}$. Furthermore, a suspension of $1 \mathrm{~mL}$ from the centrifuged mealybug samples were plated separately on modified Davis minimal agar incubated at $32{ }^{\circ} \mathrm{C}$ for $72 \mathrm{~h}$, and the microbial colonies producing clear haloes of more than $10 \mathrm{~mm}$ (antibiotic zone scale-C PW297, HiMedia, India) after incubation were further screened for lipase production.

\section{Screening for lipase production}

\section{Starter culture}

The starter culture for the screening of all qualitative and quantitative lipases was prepared by inoculating a single colony of the isolated WDB isolates separately, into $50-\mathrm{mL}$ Erlenmeyer flasks containing $10 \mathrm{~mL}$ of Davis minimal broth supplemented with olive oil $2.0 \%(\mathrm{v} / \mathrm{v})$ grown overnight at $28 \pm 2{ }^{\circ} \mathrm{C}$ and $120 \mathrm{rpm}$.

\section{Rhodamine B fluorescence-based lipase assay}

The enzyme production was screened by streaking a loopful of the starter culture on rhodamine B olive oil agar medium $(\mathrm{pH}$ 6.5) containing trypticase peptone $(8$ $\mathrm{g} / \mathrm{L})$, yeast extract $(4 \mathrm{~g} / \mathrm{L}), \mathrm{NaCl}(3 \mathrm{~g} / \mathrm{L})$, agar $(20 \mathrm{~g} / \mathrm{L})$, olive oil $2.0 \%(\mathrm{v} / \mathrm{v})$, and rhodamine B $0.001 \%(\mathrm{w} / \mathrm{v})$ for the detection of enzyme activity with three replicates for each WDB. The assay plates were incubated at $37^{\circ} \mathrm{C}$, and after $36 \mathrm{~h}$, each Petri dish was exposed to ultraviolet (UV) irradiation (UV-A, $350 \mathrm{~nm}$ ) for visualizing orange haloes around the colonies.

\section{Tributyrin agar well method for lipid hydrolysis}

Lipase production by the WDB isolates was further screened using tributyrin agar (TBA) plates containing $5.0 \mathrm{~g} / \mathrm{L}$ of peptone and $3.0 \mathrm{~g} / \mathrm{L}$ of beef extract, $20.0 \mathrm{~g} / \mathrm{L}$ of agar autoclaved and cooled to approximately $60{ }^{\circ} \mathrm{C}$, and $1 \%$ tributyrin $(\mathrm{v} / \mathrm{v})$ was filter sterilized and added to the base medium. For the lipid hydrolysis assay, $40 \mu \mathrm{L}$ of supernatant from the overnight grown WDB starter culture was filter sterilized and the cell-free culture broth was inoculated into 6-mm diameter wells cut into TBA plates using a cork borer. The plates were incubated at $28 \pm 2{ }^{\circ} \mathrm{C}$ and the zone of clearance (hydrolysis) around the colonies was observed and documented up to seven days.

\section{Enzyme production and cell growth}

The $1 \%(\mathrm{v} / \mathrm{v})$ starter culture containing $10^{9} \mathrm{cfu} / \mathrm{mL}$ was inoculated into $100-\mathrm{mL}$ Erlenmeyer flask containing $25 \mathrm{~mL}$ of medium supplemented with peptone $0.2 \%(\mathrm{w} / \mathrm{v})$, $\mathrm{NH}_{4} \mathrm{H}_{2} \mathrm{PO}_{4} 0.1 \%(\mathrm{w} / \mathrm{v}), \mathrm{NaCl} 0.25 \%(\mathrm{w} / \mathrm{v}), \mathrm{MgSO}_{4} 7 \mathrm{H}_{2} \mathrm{O}$ $0.04 \%(\mathrm{w} / \mathrm{v}), \mathrm{CaCl}_{2} .2 \mathrm{H}_{2} \mathrm{O} 0.04 \%(\mathrm{w} / \mathrm{v})$, olive oil $2.0 \%$ $(\mathrm{v} / \mathrm{v})$ at $\mathrm{pH} 7.0$, and a drop of Tween 80 as emulsifier with rotary shaker at $150 \mathrm{rpm}$ at $28 \pm 2^{\circ} \mathrm{C}$. After incubation, 
for every $12 \mathrm{~h}$, each bacterial culture was centrifuged at $10,000 \mathrm{rpm}$ for $20 \mathrm{~min}$ at $4{ }^{\circ} \mathrm{C}$, and the cell-free culture supernatant was used for the estimation of extracellular enzyme until $96 \mathrm{~h}$. Simultaneously, the cell density was evaluated by measuring the optical density at $600 \mathrm{~nm}$ against the cell-free control.

\section{Simplified p-nitrophenyl laurate assay for lipases}

The lipase activity of the WDB isolates was assayed every $12 \mathrm{~h}$ using p-nitrophenyl laurate (pNPL; SigmaAldrich, USA) as the substrate. The samples $(0.1 \mathrm{~mL})$ of WDB culture supernatants were mixed with $0.9 \mathrm{~mL}$ of the substrate solution (containing $3 \mathrm{mg}$ of pNPL dissolved in $1 \mathrm{~mL}$ propanol-2-ol, which was diluted in $9 \mathrm{~mL}$ of $50 \mathrm{mM}$ Tris- $\mathrm{HCl}$ at $\mathrm{pH} 8.0$ with $40 \mathrm{mg}$ of Triton $\mathrm{X}-100$ and $10 \mathrm{mg}$ of gum arabic). After $30 \mathrm{~min}$ of incubation at $38{ }^{\circ} \mathrm{C}$, the reaction was then terminated by adding $1 \mathrm{~mL}$ of ethanol, and the absorbance was measured spectrophotometrically (SmartSpecTM3000 UV spectrophotometer, Bio-Rad) at $410 \mathrm{~nm}$ against an enzyme-free control. In addition, one lipase unit was defined as the amount of enzyme that liberates $1 \mu \mathrm{mol}$ p-nitrophenol/min under the assay conditions described above. All enzyme assays were performed in triplicate, and the average values were calculated.

Molecular identification using 16S rDNA sequencing and phylogenetic classification

Total genomic DNA was extracted from the WDB isolates using a genomic DNA preparation kit and purified using the bacterial genomic DNA purification kit (HiMedia, India). The 16S rRNA gene from the bacterial isolates was amplified using universal eubacterial primers, 27F (AGAGTTTGATCMTGGCTCAG) and 1492R (TACGGYTACCTTGTTACGACTT; Weisburg et al., 1991). The amplified products were analyzed by electrophoresis in 1.5\% agarose gels. After the separation of polymerase chain reaction products in the agarose gel, the products were observed and documented using Alpha imager TM1200 gel documentation and analysis system. The band of the expected size was gel purified using spin columns and eluted using sterile Milli-Q water. Sanger sequencing was performed at Chromus Biotech Pvt. Ltd., Bangalore, Karnataka, India. The identity of $16 \mathrm{~S}$ rRNA sequence was established by performing a similarity search against the NCBI (National Center for Biotechnology Information), EZtaxon, and DDBJ (DNA Data Bank of Japan) nucleotide sequence databases using the Basic Local Alignment Search Tool (BLASTn) program. The phylogenetic tree of WDB isolates was constructed using the $16 \mathrm{~S}$ rRNA gene sequence of the type strains of the species obtained from the NCBI, and ClustalX program was used for multiple sequence alignment. The phylogenetic tree was constructed using the neighbor-joining (NJ) method using MEGA software package version 4.0, and bootstrapping was used to estimate the reliability of the phylogenetic reconstructions (1,000 replicates).

\section{Effect of wax degrading bacterial isolates on mortality of $\mathrm{P}$. solenopsis and $\mathrm{F}$. virgata}

Efficacy of different bacterial isolates of PSAD 1,2,3,5,6,7,8,9 and insecticide Acetamiprid 20\% Soluble Powder (SP) against $P$. solenopsis and F. virgata were tested under laboratory conditions. Selected bacterial isolates under study were inoculated in $50 \mathrm{ml}$ Erlenmeyer flasks containing $10 \mathrm{ml}$ of Davis minimal broth containing mealy wax $(2 \mathrm{~g}$ per litre $)$ at $28^{\circ} \mathrm{C}$ and incubated into rotary shaker at $120 \mathrm{rpm}$. Each of the $48 \mathrm{~h}$ grown cultures were then centrifuged at $4,225 \mathrm{~g}$ for $10 \mathrm{~min}$ and the cell pellets were diluted with $10 \mathrm{ml}$ sterile saline solutions separately. The optical densities (ODs) of these solutions were measured at wavelength of $600 \mathrm{~nm}$ by UV-Vis Spectrophotometer and viable cell count was determined by plate count method. Spraying solutions for efficacy studies were prepared by adding $0.05 \%$ Arabic gum and Tween $80\left(10 \mu \mathrm{ml}^{-1}\right)$ to the above bacterial suspensions having approximately $3 \times 10^{8}$ of each bacterial isolate. The solution without bacterial isolates served as control. Susceptibility was evaluated by directly dipping mealybug nymphs and adults in $30 \mathrm{ml}$ of bacterial formulation and insecticide for $5 \mathrm{sec}$. Three replicates of 20 insects were used in each experiment. After treatment, each replication was kept in a separate Petriplates $(90 \times 15 \mathrm{~mm})$ containing moist Whatman No.1 paper and allowed to feed on disinfected cotton leaves and incubated at $25 \pm 1^{\circ} \mathrm{C}, 70 \pm 10$ percent relative humidity. Mortality was corrected by Abbotts formula. Both nymphal and adult mortality was recorded at 24, 48 and $72 \mathrm{~h}$ after treatment (HAT). The significance of the difference in all bioassay experiments was determined by analysis of variance (ANOVA) using least significant difference (LSD) at $\mathrm{p}<0.01$.

\section{RESULTS AND DISCUSSION}

A vast array of wax-degrading microorganisms exists in nature (Elisa et al., 2006); however, only a few are documented and used in commercial applications. To use these elite microorganisms in various fields, their process of wax degradation has gain attention. The WDB from mealybugs have proved their effectiveness in the microbial surfactant production, a key process involved in complex hydrocarbon degradation (Arunkumar et al., 2017), and this study aimed to visualize the lipaseproducing ability of these novel WDB strains, coupled 
with their possible utilization for the biological control of mealybugs infesting cotton. This study has originated from a previous study in which lipolytic microorganisms belonging to different genera including Bacillus, Brevibacterium, Corynebacterium, Staphylococcus, Klebsiella, and Stenotrophomonas were isolated from the silkworm Bombyx mori L. (Feng et al., 2011).

Table I. Screening of the wax degrading bacterial (WDB) isolates for lipase production on rhodamine B and tributyrin agar well.

\begin{tabular}{|c|c|c|c|}
\hline WDB isolate & $\begin{array}{l}\text { Rhodomine } \\
\text { B assay* }\end{array}$ & $\begin{array}{l}\text { Maximum hydrolysis } \\
\text { reached (days) }\end{array}$ & $\begin{array}{l}\text { Activi- } \\
\text { ty** }\end{array}$ \\
\hline PSAD 1 & $\mathrm{D}$ & 7 & +++ \\
\hline PSAD 2 & $\mathrm{D}$ & 4 & +++ \\
\hline PSAD 3 & $\mathrm{D}$ & 5 & ++ \\
\hline PSAD 4 & ND & 7 & --- \\
\hline PSAD 5 & $\mathrm{D}$ & 7 & ++ \\
\hline PSAD 6 & $\mathrm{D}$ & 6 & +++ \\
\hline PSAD 7 & $\mathrm{D}$ & 5 & +++ \\
\hline PSAD 8 & $\mathrm{D}$ & 6 & +++ \\
\hline PSAD 9 & $\mathrm{D}$ & 6 & +++ \\
\hline PSAD 10 & ND & 7 & --- \\
\hline PSAD 11 & ND & 7 & --- \\
\hline PSAD 12 & ND & 7 & --- \\
\hline PSAD 13 & ND & 7 & --- \\
\hline PSAD 14 & ND & 7 & --- \\
\hline PSAD 15 & ND & 7 & --- \\
\hline PSAD 16 & ND & 7 & --- \\
\hline PSAD 17 & ND & 7 & --- \\
\hline PSAD 18 & ND & 7 & --- \\
\hline PSAD 19 & ND & 7 & --- \\
\hline PSAD 20 & ND & 7 & --- \\
\hline PSAD 21 & $\mathrm{D}$ & 6 & + \\
\hline PSAD22 & ND & 7 & --- \\
\hline PSAD23 & ND & 7 & --- \\
\hline
\end{tabular}

*D, an orange halo zone detected; ND- no orange halo zone detected; ** + , weak activity (zone greater than $15 \mathrm{~mm}$ ); ++ , medium activity (zone greater than 20mm); +++, strong activity (zone greater than $25 \mathrm{~mm}$ ); ---, no activity (no zone).

Screening of wax-degrading bacteria for lipase production

The fluorescence-based interaction of rhodamine B with fatty acids released during the enzymatic hydrolysis of triglycerides is an effective qualitative assay for lipase (Jette and Ziomek, 1994). The primary screening of the 23 WDB isolates by rhodamine B assay resulted in nine lipase-positive bacterial isolates (PSAD1, PSAD2, PSAD3, PSAD5, PSAD6, PSAD7, PSAD8, PSAD9, and PSAD21) from $P$. solenopsis and $F$. virgata (Table I). Other 14 isolates from $D$. mangiferae and $P$. marginatus did not produce any orange halo zone, which initially proved their ineffectiveness in lipase production. The complex formation between uranyl fatty acid ion and cationic rhodamine B during the lipid hydrolysis by lipase and further exposure to longer wavelengths such as UV radiation result in the excited dimmers of the rhodamine B complex-liberating fluorescence (Boonmahome, 2013).

Further screening through TBA well method showed that PSAD1, PSAD2, PSAD6, PSAD7, PSAD8, and PSAD9 (zone greater than $25 \mathrm{~mm}$ ) had the highest activity, followed by PSAD3 and PSAD5 (zone greater than $20 \mathrm{~mm}$ ), whereas PSAD21 showed the least activity (zone less than $20 \mathrm{~mm}$ ). Lipase-producing strains can be conventionally screened on tributyrylglycerol or TBA plates, and the zone of tributyrin hydrolysis is a clear indicative of lipase activity (Gupta et al., 2003). The effectiveness of tributyrin hydrolysis was shown in the previous studies on lipaseproducing microorganisms, such as Pseudomonas fragi, Staphylococcus aureus, Burkholderia glumae, Clostridium tetanomorphum, Lactobacillus plantarum, L. delbrueckii subsp. bulgaricus, L. sakei, L. reuteri, Enterococcus faecium, and Leuconostoc citreum (Petersen and Daniel, 2006; Dincer and Kivanc, 2018). As PSAD4, PSAD10, PSAD11, PSAD12, PSAD13, PSAD14, PSAD15, PSAD16, PSAD17, PSAD18, PSAD20, PSAD22, and PSAD23 showed negative results in screening and PSAD21 with least tributyrin hydrolyzing efficiency was rejected, the other eight potential strains were evaluated for lipase quantification and cell growth studies.

Comparison of cell growth and lipase production in wax-degrading bacteria

Initially, the starter cultures of the potential eight WDB isolates were grown on olive oil as a carbon source, and the lipase quantification and growth analysis were performed on a defined medium containing peptone and olive oil for accurate results, as the media supplemented with olive oil is prevalently used for the screening and quantification of lipase-positive microorganisms (Martinez and SoberonChavez, 2001). Further quantification of lipase production by pNPL assay showed that the isolate PSAD2 had higher lipase production of $2.3 \mathrm{U} / \mathrm{mL}$, followed by PSAD7 (1.7 $\mathrm{U} / \mathrm{mL}$ ), whereas PSAD3 and PSAD5 showed least lipase production of $0.032 \mathrm{U} / \mathrm{mL}$ and $0.024 \mathrm{U} / \mathrm{mL}$, respectively, between 48 and $60 \mathrm{~h}$ of incubation in the given medium (Fig. 1) and thereafter started declining. The finding was analogous to the results obtained by Gowland et al. (1987) for Bacillus species (4 U/mL) and Hamid et al. (2003) 


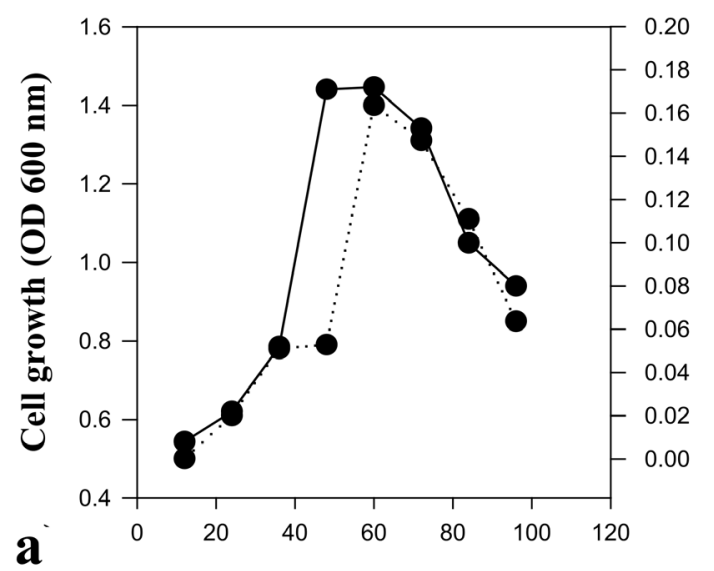

Time (h)

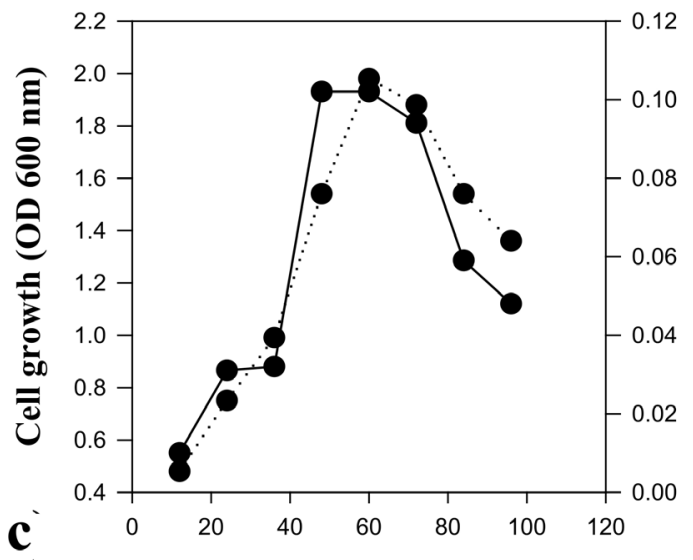

Time (h)

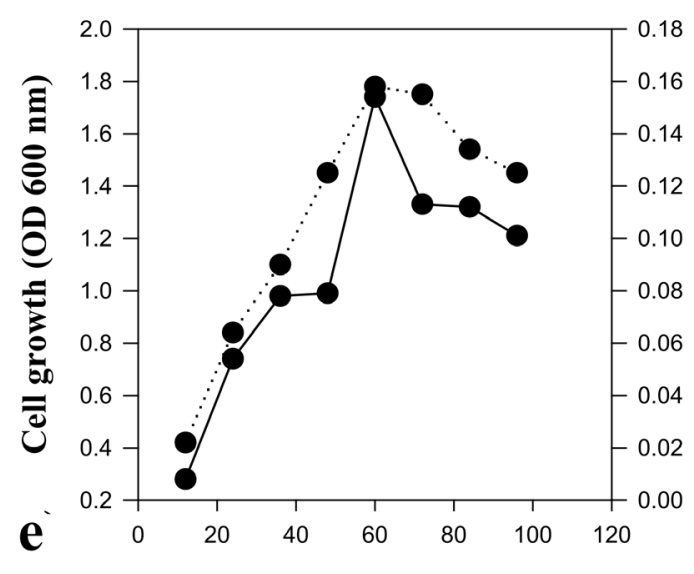

Time (h)

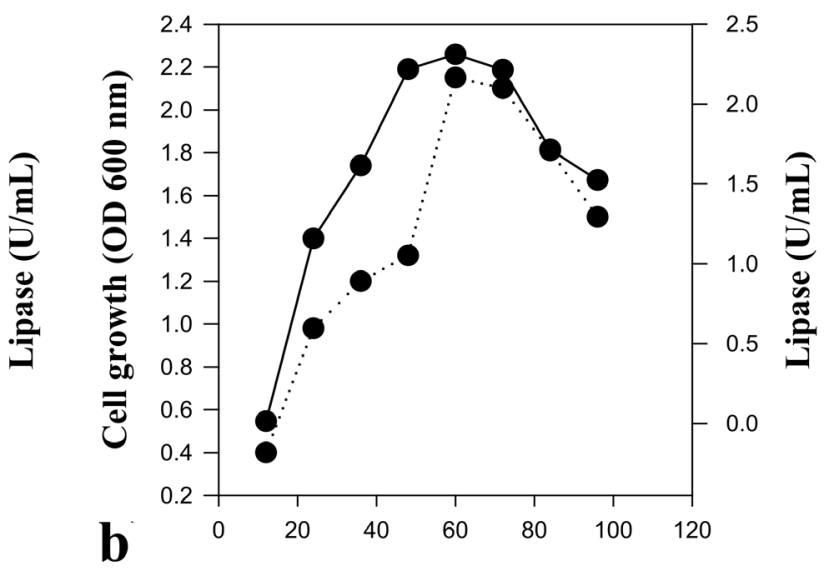

Time (h)

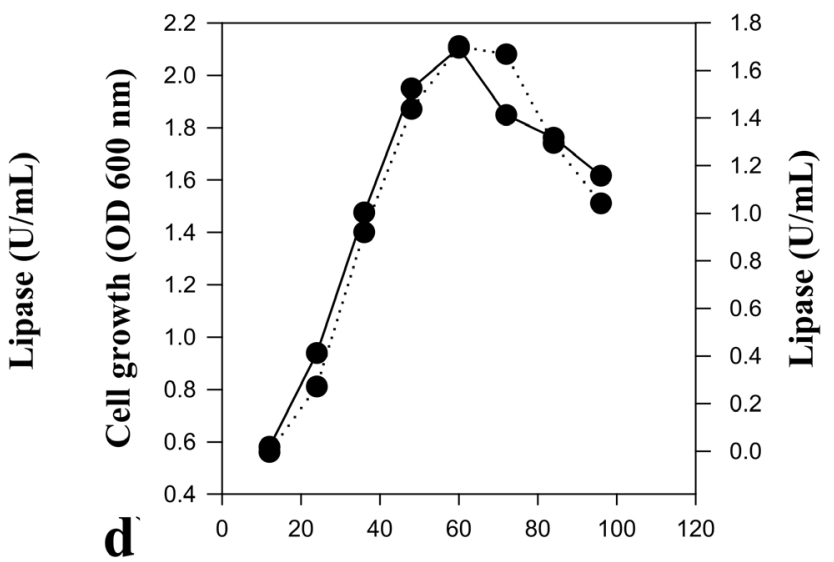

Time (h)

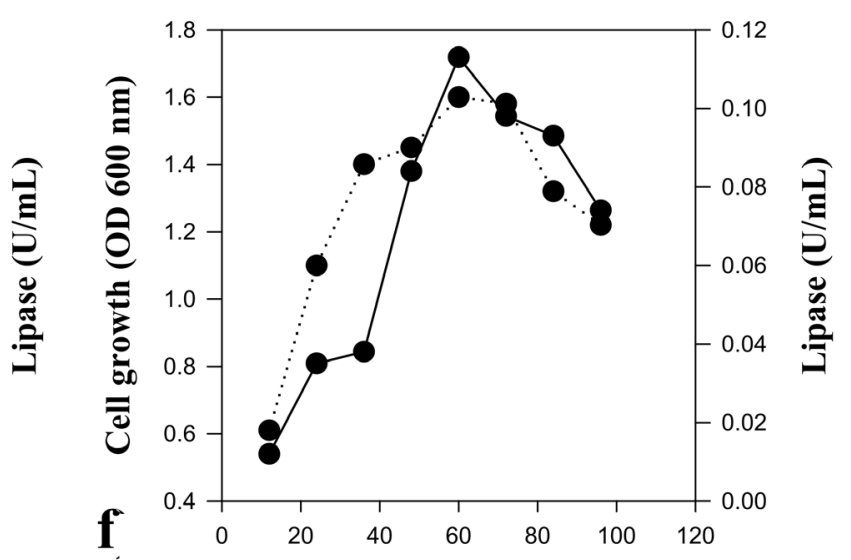

Time (h)

\section{… Time (h) vs Cell growth - optical density (OD) at $600 \mathrm{~nm}$} Time (h) vs Lipase (U/mL)

Fig. 1. Comparison of cell growth and lipase production in wax degrading bacteria (WDB); a) PSADI, b) PSAD2, c) PSAD6, d), PSAD7, e) PSAD8, f) PSAD9. 


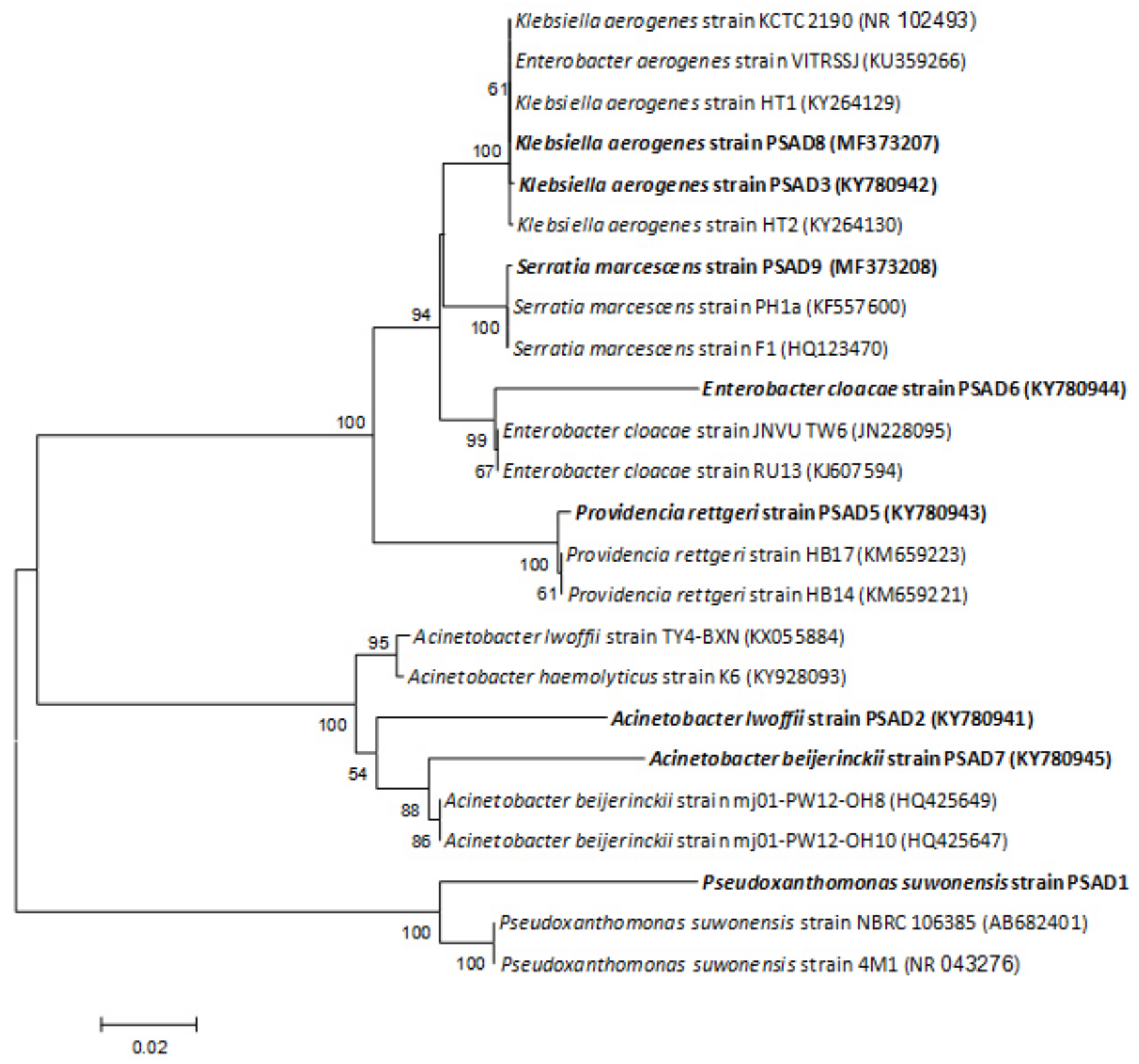

Fig. 2. Phylogenetic classification of wax degrading bacteria isolated from cotton mealybugs by Neighbor-joining phylogenetic tree based on complete 16S rRNA sequences. Bar, 0.02 nucleotide changes per position. The wax degrading bacterial strains obtained in this study shown in blood. A bootstrap value $\geq 50$ is shown.

for Bacillus species $(4.58 \mathrm{U} / \mathrm{mL})$ and Ralstonia paucula $(3.51 \mathrm{U} / \mathrm{mL})$. The growth of the eight screened positive WDB isolates PSAD1, PSAD2, PSAD3, PSAD5, PSAD6, PSAD7, PSAD8, and PSAD9 reached the maximum cell density at $60 \mathrm{~h}$ after incubation and decreased after completing the stationary phase in $72 \mathrm{~h}$. The growth curve analysis of the eight positive WDB isolates confirmed that lipase production is associated with the growth phase of the isolates, and after reaching the stationary phase, the lipase production and cell growth decreased, which may be because of the depletion of nutrients, as confirmed by Biswas et al. (2016).

Molecular-based phylogeny of the wax-degrading bacterial isolates

The genomic DNA of the WDB isolates was amplified, and a phylogenetic tree constructed using $\mathrm{NJ}$ method with 16S rRNA amplified gene sequence (Fig. 2). 
Table II. Effect of wax degrading bacterial isolates on mortality of Phenacoccus solenopsis (Tinsley).

\begin{tabular}{|c|c|c|c|c|c|c|}
\hline \multirow[t]{2}{*}{ Treatments } & \multicolumn{3}{|c|}{ Nymphal mortality (\%) } & \multicolumn{3}{|c|}{ Adult mortality (\%) } \\
\hline & 24 HAT & 48 HAT & 72 HAT & 24 HAT & 48 HAT & 72 HAT \\
\hline $\begin{array}{l}\text { Pseudoxanthomonas suwonensis } \\
\text { PSAD1 }\end{array}$ & $10.20\left(18.63^{\mathrm{E}}\right)$ & $13.55\left(21.60^{\mathrm{E}}\right)$ & $20.27\left(26.76^{\mathrm{E}}\right)$ & $00.00\left(02.50^{\mathrm{F}}\right)$ & $15.11\left(22.87^{\mathrm{F}}\right)$ & $21.50\left(27.62^{\mathrm{E}}\right)$ \\
\hline Acinetobacter lwoffii PSAD2 & $15.87\left(23.48^{\mathrm{C}}\right)$ & $26.74\left(31.14^{\mathrm{B}}\right)$ & $50.26\left(45.15^{\mathrm{B}}\right)$ & $10.20\left(18.62^{\mathrm{E}}\right)$ & $40.83\left(39.71^{\mathrm{B}}\right)$ & $50.10\left(45.06^{\mathrm{B}}\right)$ \\
\hline Klebsiella aerogenes PSAD3 & $00.00\left(02.50^{\mathrm{F}}\right)$ & $10.20\left(18.62^{\mathrm{F}}\right)$ & $15.14\left(22.90^{\mathrm{G}}\right)$ & $00.00\left(02.50^{\mathrm{F}}\right)$ & $00.00\left(2.50^{\mathrm{Gv}}\right)$ & $10.20\left(18.62^{\mathrm{F}}\right)$ \\
\hline Providencia rettgeri PSAD5 & $15.12\left(22.88^{\mathrm{C}}\right)$ & $20.17\left(26.68^{\mathrm{D}}\right)$ & $22.17\left(28.09^{\mathrm{E}}\right)$ & $10.33\left(18.75^{\mathrm{E}}\right)$ & $23.33\left(28.88^{\mathrm{D}}\right)$ & $27.14\left(31.40^{\mathrm{D}}\right)$ \\
\hline Enterobacter cloacae PSAD6 & $00.00\left(02.50^{\mathrm{F}}\right)$ & $10.20\left(18.63^{\mathrm{F}}\right)$ & $17.45\left(24.69^{\mathrm{F}}\right)$ & $00.00\left(02.50^{\mathrm{F}}\right)$ & $15.14\left(22.90^{\mathrm{F}}\right)$ & $20.17\left(26.69^{\mathrm{E}}\right)$ \\
\hline Acinetobacter beijerinckii PSAD7 & $13.33\left(21.41^{\mathrm{D}}\right)$ & $27.13\left(31.39^{\mathrm{B}}\right)$ & $42.45\left(40.66^{\mathrm{C}}\right)$ & $15.48\left(23.17^{\mathrm{C}}\right)$ & $30.58\left(33.57^{\mathrm{C}}\right)$ & $42.17\left(40.49^{\mathrm{C}}\right)$ \\
\hline Klebsiella aerogenes PSAD8 & $20.54\left(26.95^{\mathrm{B}}\right)$ & $24.10\left(29.40^{C}\right)$ & $28.41\left(32.21^{\mathrm{D}}\right)$ & $21.04\left(27.30^{\mathrm{B}}\right)$ & $21.04\left(27.30^{\mathrm{DE}}\right)$ & $25.78\left(30.51^{\mathrm{D}}\right)$ \\
\hline Serratia marcescens PSAD9 & $10.20\left(18.62^{\mathrm{E}}\right)$ & $24.78\left(29.85^{\mathrm{C}}\right)$ & $27.12\left(31.38^{\mathrm{D}}\right)$ & $11.47\left(19.80^{\mathrm{D}}\right)$ & $18.24\left(25.28^{\mathrm{E}}\right)$ & $28.35\left(32.17^{\mathrm{D}}\right)$ \\
\hline Acetamiprid $20 \% \mathrm{SP}$ & $25.12\left(30.08^{\mathrm{A}}\right)$ & $31.41\left(34.09^{\mathrm{A}}\right)$ & $74.54\left(59.70^{\AA}\right)$ & $25.17\left(30.11^{\mathrm{A}}\right)$ & $48.33\left(44.04^{\mathrm{A}}\right)$ & $71.69\left(57.87^{\mathrm{A}}\right)$ \\
\hline Control & $00.00\left(02.50^{\mathrm{F}}\right)$ & $0.00\left(02.50^{\mathrm{G}}\right)$ & $0.00\left(02.50^{\mathrm{H}}\right)$ & $00.00\left(02.50^{\mathrm{F}}\right)$ & $00.00\left(02.50^{\mathrm{G}}\right)$ & $00.00\left(02.50^{\mathrm{G}}\right)$ \\
\hline General mean & 16.95 & 24.39 & 31.40 & 14.77 & 24.96 & 31.29 \\
\hline p-Value & $<.0001$ & $<.0001$ & $<.0001$ & $<.0001$ & $<.0001$ & $<.0001$ \\
\hline $\mathrm{CV}(\%)$ & 2.11 & 1.46 & 1.21 & 1.68 & 2.35 & 1.91 \\
\hline $\mathrm{SE}(\mathrm{d})$ & 0.292 & 0.292 & 0.309 & 0.203 & 0.478 & 0.488 \\
\hline Tukey HSD@1\% & 1.2783 & 1.2787 & 1.3558 & 0.8884 & 2.0972 & 2.1397 \\
\hline
\end{tabular}

In a column means followed by common letter are not significantly different ( $\alpha=0.01$ in all cases). Figures in the parentheses are arcsine transformed values; HAT, hours after treatment; *Zero proportion was removed by using the equation $1 / 4 \mathrm{n} \mathrm{x} \mathrm{100;} \mathrm{n,} \mathrm{number} \mathrm{of} \mathrm{insect} \mathrm{taken} \mathrm{for} \mathrm{treatment.}$

Table III. Effect of wax degrading bacterial isolates on mortality of Ferrisia virgata (Cockerell).

\begin{tabular}{|c|c|c|c|c|c|c|}
\hline \multirow[t]{2}{*}{ Treatment } & \multicolumn{3}{|c|}{ Nymphal mortality (\%) } & \multicolumn{3}{|c|}{ Adult mortality (\%) } \\
\hline & 24 HAT & 48 HAT & 72 HAT & 24 HAT & 48 HAT & 72 HAT \\
\hline $\begin{array}{l}\text { Pseudoxanthomonas suwon- } \\
\text { ensis PSAD1 }\end{array}$ & $11.33\left(19.67^{\mathrm{D}}\right)$ & $14.62\left(22.48^{\mathrm{E}}\right)$ & $18.68\left(25.60^{\mathrm{F}}\right)$ & $10.20\left(18.62^{\mathrm{E}}\right)$ & $17.89\left(25.02^{\mathrm{F}}\right)$ & $19.74\left(26.38^{\mathrm{D}}\right)$ \\
\hline Acinetobacter lwoffii PSAD2 & $10.20\left(18.63^{\mathrm{E}}\right)$ & $30.54\left(33.55^{\mathrm{B}}\right)$ & $51.88\left(46.08^{\mathrm{B}}\right)$ & $15.22\left(22.96^{\mathrm{C}}\right)$ & $32.18\left(34.56^{\mathrm{C}}\right)$ & $50.09\left(45.05^{\mathrm{B}}\right)$ \\
\hline Klebsiella aerogenes PSAD3 & $00.00\left(02.50^{\mathrm{G}}\right)$ & $00.00\left(02.50^{\mathrm{G}}\right)$ & $10.20\left(18.62^{\mathrm{H}}\right)$ & $00.00\left(02.50^{\mathrm{F}}\right)$ & $00.00\left(02.50^{\mathrm{G}}\right)$ & $00.00\left(02.50^{\mathrm{F}}\right)$ \\
\hline Providencia rettgeri PSAD5 & $11.89\left(20.17^{\mathrm{CD}}\right)$ & $14.17\left(22.11^{\mathrm{E}}\right)$ & $25.78\left(30.51^{\mathrm{DE}}\right)$ & $12.98\left(21.11^{\mathrm{D}}\right)$ & $23.33\left(28.88^{\mathrm{D}}\right)$ & $27.14\left(31.40^{\mathrm{C}}\right)$ \\
\hline Enterobacter cloacae PSAD6 & $10.20\left(18.62^{\mathrm{E}}\right)$ & $11.33\left(19.67^{\mathrm{F}}\right)$ & $14.62\left(22.48^{\mathrm{G}}\right)$ & $00.00\left(02.50^{\mathrm{F}}\right)$ & $00.00\left(02.50^{\mathrm{G}}\right)$ & $15.22\left(22.96^{\mathrm{E}}\right)$ \\
\hline $\begin{array}{l}\text { Acinetobacter beijerinckii } \\
\text { PSAD } 7\end{array}$ & $20.54\left(26.95^{\mathrm{B}}\right)$ & $27.13\left(31.39^{\mathrm{C}}\right)$ & $45.40\left(42.36^{\mathrm{C}}\right)$ & $16.95\left(24.31^{\mathrm{B}}\right)$ & $34.15\left(35.76^{\mathrm{B}}\right)$ & $47.92\left(43.81^{\mathrm{B}}\right)$ \\
\hline Klebsiella aerogenes PSAD8 & $09.17\left(17.63^{\mathrm{F}}\right)$ & $17.18\left(24.48^{\mathrm{D}}\right)$ & $24.25\left(29.50^{\mathrm{E}}\right)$ & $11.04\left(19.41^{\mathrm{E}}\right)$ & $24.04\left(29.36^{\mathrm{D}}\right)$ & $24.04\left(29.36^{\mathrm{C}}\right)$ \\
\hline Serratia marcescens PSAD9 & $12.35\left(20.57^{\mathrm{C}}\right)$ & $28.78\left(32.44^{\mathrm{BC}}\right)$ & $28.78\left(32.44^{\mathrm{D}}\right)$ & $14.68\left(22.53^{\mathrm{C}}\right)$ & $21.45\left(27.59^{\mathrm{E}}\right)$ & $27.14\left(31.40^{\mathrm{C}}\right)$ \\
\hline Acetamiprid $20 \% \mathrm{SP}$ & $32.12\left(34.52^{\mathrm{A}}\right)$ & $41.58\left(40.15^{\mathrm{A}}\right)$ & $75.89\left(60.62^{\mathrm{A}}\right)$ & $37.98\left(38.04^{\mathrm{A}}\right)$ & $50.77\left(45.44^{\mathrm{A}}\right)$ & $47.14\left(59.45^{\mathrm{A}}\right)$ \\
\hline Control & $0.00\left(02.50^{\mathrm{G}}\right)$ & $00.00\left(02.50^{\mathrm{G}}\right)$ & $00.00\left(02.50^{\mathrm{I}}\right)$ & $00.00\left(02.50^{\mathrm{F}}\right)$ & $00.00\left(02.50^{\mathrm{G}}\right)$ & $00.00\left(02.50^{\mathrm{F}}\right)$ \\
\hline General mean & 18.18 & 23.13 & 31.07 & 17.45 & 23.41 & 29.48 \\
\hline p-Value & $<.0001$ & $<.0001$ & $<.0001$ & $<.0001$ & $<.0001$ & $<.0001$ \\
\hline $\mathrm{CV}(\%)$ & 1.28 & 1.36 & 2.27 & 1.62 & 0.65 & 2.49 \\
\hline $\mathrm{SE}(\mathrm{d})$ & 0.189 & 0.256 & 0.576 & 0.231 & 0.123 & 0.600 \\
\hline Tukey HSD@1\% & 0.8302 & 1.1231 & 2.5251 & 1.0113 & 0.5407 & 2.6299 \\
\hline
\end{tabular}

In a column means followed by common letter are not significantly different $(\alpha=0.01$ in all cases). Figures in the parentheses are arcsine transformed values; HAT- hours after treatment; *Zero proportion was removed by using the equation $1 / 4 \mathrm{n}$ x 100; n, number of insect taken for treatment. 
The phylogenetic tree inferred from 16S rRNA gene sequences confirmed that the bacterial isolates were Pseudoxanthomonas suwonensis PSAD1 (GenBank accession number KY780940), Acinetobacter lwoffii PSAD2 (GenBank accession number KY780941), Klebsiella aerogenes PSAD3 (GenBank accession number KY780942), Providencia rettgeri PSAD5 (GenBank accession number KY780943), Enterobacter cloacae PSAD6 (GenBank accession number KY780944), A. beijerinckii PSAD7 (GenBank accession number KY780945), K. aerogenes PSAD8 (GenBank accession number MF373207), and S. marcescens PSAD9 (GenBank accession number MF373208); the sequences are presently available in the NCBI GenBank database. In a previous study by Syihab et al. (2017), a thermostable and alcoholtolerant lipase from Pseudoxanthomonas species was isolated from domestic compost. On the basis of 16S rRNA gene sequence analysis, 12 strains of Bacillus, Klebsiella, Pseudomonas, and Enterobacter were collected from soil and water samples and optimized for lipase production (Lin et al., 2012). Extracellular novel lipase-producing Acinetobacter species have been isolated from olive oil-enriched soil (Wang et al., 2011) and the subalpine region of western Himalaya, India (Kasana et al., 2008).

Mortality of $\mathrm{P}$. solenopsis and $\mathrm{F}$. virgata

The insecticidal effects of entomopathogenic microbes could be directly linked to a range of extracellular enzymes including chitinases, lipases, esterases and proteases that can degrade the major components of insect cuticle, which may lead to the further bacterial infection of the internal organelles and also for the entry of other EPF (Usta, 2013). The present study indicated that the nymph and adult of $P$. solenopsis and $F$. virgata were found to be susceptible to all the bacterial isolates tested. The recorded nymphal and adult mortality is probably due to the hydrolytic lipase enzyme produced by the wax degrading bacterial isolates which may damage the waxy cuticle. Among the bacterial isolates A. lwoffii PSAD2 and A. beijerinckii PSAD7 produced more than 50\% mortality against $P$. solenopsis nymph and adults, whereas chemical insecticide Acetamiprid 20\% SP caused more than 70\% mortality (Table II). Interestingly, bacterial isolate $A$. lwoffii PSAD2 and A. beijerinckii PSAD7 caused more than $47 \%$ adult mortality against F.virgata which was on par with the chemical insecticide Acetamiprid 20\% SP (Table III) confirmed that these bacterial entomopathogens could be used in the control of mealybugs if developed into a suitable biocontrol formulation. Salunkhe et al. (2013), in his investigation against wax coated insect pests highlighted that degradation of their waxy cuticle through wax degrading bacterial applications could be a potential tool for biocontrol of mealybugs. However, the degree of susceptibility varied with different isolates as well as the exposure period. Apart from extracellular enzyme production the bacterial entomopathogens belonging to the genera Serratia, Pseudomonas, Photorhabdus, Yersinia and Xenorhabdus have reported to produce variety of metabolites acting as potent insecticides (Ruiu, 2015) may be a reason for the variation in susceptibility of the mealybugs to the wax degrading bacterial isolates.

\section{CONCLUSIONS}

Microbial lipases are widely used in various industries, as they are economical and eco-friendly. Previously, lipases from Bacillus, Pseudomonas, Alcaligenes, Arthrobacter, lactic acid bacteria, and Chromobacterium were used commercially. However, the interest in lipase-producing Acinetobacter is recently gaining importance for their multiple applications with little implications. This study is the first to report on lipase-producing WDB from mealybugs infesting cotton, highly confirmed with screening and identification studies. Furthermore, this study explored the potential of these lipase-producing WDB isolates in developing a potential microbial insecticide against mealybugs.

\section{ACKNOWLEDGMENTS}

This research was financially supported by Science and Engineering Research Board (SERB), Department of Science and Technology, Government of India to Dr. Arunkumar Nagarathinam in the form of SERB National Post-Doctoral Fellowship (File Number: PDF/2015/000844). The authors greatly acknowledge Indian Council of Agricultural Research- Central Institute for Cotton Research (ICAR-CICR), Nagpur, Maharashtra, India for the institutional support.

\section{Statement of conflict of interest}

The authors have declared no conflict of interest.

\section{REFERENCES}

Arunkumar, N., Banu, J.G., Gopalakrishnan, N. and Prakash, A.H., 2017. Isolation, screening and characterization of microbial surfactants producing wax degrading bacteria from cotton mealybugs, Phenacoccus solenopsis Tinsley and Ferrisia virgata Cockerell (Homoptera: Pseudococcidae). J. Ent. Zool. Stud., 5: 1191-1195.

Arunkumar, N., Banu, J.G., Gopalakrishnan, N. and Prakash, A.H. 2018. The biochemical correlation 
between the epicuticular wax of upland cotton (Gossypium hirsutum L.) and the wax of different mealybug species. Phytoparasitica, 46: 145-152. https://doi.org/10.1007/s12600-018-0656-8

Babu, I.S. and Rao, G.H., 2007. Lipase production by Yarrowia lipolytica NCIM 3589 in solid state fermentation using mixed substrate. Res. J. Microbiol., 2: 469-474. https://doi.org/10.3923/ jm.2007.469.474

Benelli, G. and Rajasekar, A., 2017. Biosurfactant and enzyme mediated crude oil degradation by Pseudomonas stutzeri $\mathrm{NA}_{3}$ and Acinetobacter baumannii $\mathrm{MN}_{3}$. 3 Biotech., 7: 278. https://doi. org/10.1007/s13205-017-0902-7

Biswas, M., Sahoo, S., Maiti, S. and Roy, S., 2016. Isolation of lipase producing bacteria and determination of their lipase activity from a vegetative oil contaminated soil. Int. Res. J. appl. Basic Sci., 1: 4-7.

Boonmahome, P., 2013. Lipase-producing bacterium and its enzyme characterization. J. Life Sci. Technol., 1: 196-200. https://doi.org/10.12720/ jolst.1.4.196-200

Chavan, S.B., 2009. Biocontrol of insect pests in agriculture using chitinolytic enzyme complex of Myrothecium verrucaria. Ph.D. Dissertation, National chemical laboratory of Pune, India.

Dincer, E. and Kivanc, M., 2018. Lipolytic activity of lactic acid bacteria isolated from Turkish pastirma. Anadolu Univ. J. Sci. Technol., 7: 12-19. https:// doi.org/10.18036/aubtdc.306292

Elisa, D., Boeckelmann, U., Braun, B., Diehl, D., Schaumann, G.E. and Grohmann, E., 2006. Waxdegrading bacteria influence water repellency of soil. Bioresour. Technol., 50: 1-12.

Feng, W., Wang, X.Q., Zhou, W., Liu, G.Y. and Wan, Y.J., 2011. Isolation and characterization of lipaseproducing bacteria in the intestine of the silkworm, Bombyx mori, reared on different forage. J. Insect Sci., 11: 135.https://doi.org/10.1673/031.011.13501

Gołębiowski, M., Boguś, M.I., Paszkiewicz, M. and Stepnowski, P., 2011. Cuticular lipids of insects as a potential biofungicides: Methods of lipids composition analysis. Anal. Bioanal. Chem., 399: 3177-3191. https://doi.org/10.1007/s00216-0104439-4

Gowland, P., Kernick, M. and Sundaram, T.K., 1987. Thermophilic bacterial isolates producing lipase. FEMS Microbiol. Lett., 48: 339-343. https://doi. org/10.1111/j.1574-6968.1987.tb02621.x

Gupta, R., Rathi, P., Gupta, N. and Bradoo, S., 2003. Lipase assays for conventional and molecular screening: An overview. Biotechnol. appl. Biochem., 37: 63-71. https://doi.org/10.1042/ BA20020059

Hamid, N.S.A, Zen, H.B., Tein, O.B., Halifah, Y.M. and Saari, N., 2003. Screening and identification of extracellular lipase-producing thermophilic bacteria from a Malaysian hot spring. World $J$. Microbiol. Biotechnol., 19: 961-968. https://doi. org/10.1023/B:WIBI.0000007330.84569.39

Hansen, J.D., Dietrich, C., Xia, Y., Xu, X., Wen, T.J., Delledonne, M., Robertson, D.S., Schnable, P.S. and Nikolau, B.J., 1997. Physiology, biochemistry and molecular biology of plant lipids: Molecular biology of genes involved in cuticular wax biosynthesis. Academic Publishers, Dordrecht, The Netherlands. https://doi.org/10.1007/978-94-0172662-7 106

Jette, J.F. and Ziomek, E., 1994. Determination of lipase activity by a rhodamine-triglyceride-agarose assay. Anal. Biochem., 219: 256-260. https://doi. org/10.1006/abio.1994.1265

Jetter, R., Kunst, L. and Samuels, A.L., 2006. Biology of the plant cuticle: Composition of plant cuticular waxes. Blackwell Publishing Limited, United Kingdom.

Kasana, R.C, Kaur, B. and Yadav, S.K., 2008. Isolation and identification of a psychrotrophic Acinetobacter sp. CR9 and characterization of its alkaline lipase. J. Basic Microbiol., 48: 207-212. https://doi.org/10.1002/jobm.200700160

Korany, S.M., Mansour, A.N., El-Hendawy, H.H., Kobisi, A.N.A. and Aly, H.H., 2019. Entomopathogenic efficacy of the chitinolytic bacteria: Aeromonas hydrophila isolated from Siwa Oasis, Egypt. Egypt. J. Biol. Pest Contr., 29: 16. https://doi.org/10.1186/s41938-019-0116-x

Lin, J.F, Lin, Q., Li, J. and Fei Z.A., 2012. Bacterial diversity of lipase-producing strains in different soils in southwest of China and characteristics of lipase. Afri. J. Microbiol. Res., 6: 3797-3806. https://doi.org/10.5897/AJMR12.444

Madeira Jr, J.V., Contesini, F.J., Calzado, F., Rubio, M.V., Zubieta, M.P., Lopes, D.B. and de Melo, R.R., 2017. Agro-industrial residues and microbial enzymes: An overview on the eco-friendly bioconversion into high value-added products. Biotechnol. Microbial. Enzymes, 1: 475-511. https://doi.org/10.1016/B978-0-12-8037256.00018-2

Martinez, A. and Soberon-Chavez G., 2001. Characterization of the lipA gene encoding the major lipase from Pseudomonas aeruginosa strain 
IGB83. Appl. Microbiol. Biotechnol., 56: 731-735. https://doi.org/10.1007/s002530100724

Nguyen, S., Webb, H., Mahon, P., Crawford, R. and Ivanova, E., 2014. Natural insect and plant micro-/ nano structured surfaces: An excellent selection of valuable templates with super hydrophobic and selfcleaning properties. Molecules, 19: 13614-13630. https://doi.org/10.3390/molecules 190913614

Petersen, M. and Daniel R., 2006. Purification and characterization of an extracellular lipase from Clostridium tetanomorphum. World J. Microbiol. Biotechnol., 22: 431-435. https://doi.org/10.1007/ s11274-005-9052-x

Rajan, A., Kumar, D.R.S. and Nair A.J., 2011. Isolation of a novel alkaline lipase producing fungus Aspergillus fumigatus MTCC 9657 from aged and crude rice bran oil and quantification by HPTLC. Int. J. biol. Chem., 5: 116-126. https://doi. org/10.3923/ijbc.2011.116.126

Roper, M.M., 2004. The isolation and characterization of bacteria with the potential to degrade waxes that cause water repellency in sandy soils. Aust. J. Soil Res., 42: 427-434. https://doi.org/10.1071/ SR03153

Ruiu, L., 2015. Insect pathogenic bacteria in integrated pest management. Insects, 6: 352-367. https://doi. org/10.3390/insects6020352

Salunkhe, R.B., Patil, C.D., Salunke, B.K., Rosas-
García N.M. and Patil, S.V., 2013. Effect of wax degrading bacteria on life cycle of the pink hibiscus mealybug, Maconellicoccus hirsutus (Green) (Hemiptera: Pseudococcidae). BioControl, 58: 535542. https://doi.org/10.1007/s10526-013-9513-3

Syihab, S.F., Madayanti, F., Akhmaloka, A. and Widhiastuty, M.P., 2017. Purification and characterization of thermostable and alcohol tolerant lipase from Pseudoxanthomonas sp. Afr. J. Biotechnol., 16: 1670-1677. https://doi. org/10.5897/AJB2017.16044

Usta, C., 2013. Microorganisms in biological pest control- a review (bacterial toxin application and effect of environmental factors). Curr. Progr. Biol. Res., 13: 287-317. https://doi.org/10.5772/55786

Wang, H.K., Shao, J., Wei, Y.J., Zhang, J. and Qi, W., 2011. A novel low-temperature alkaline lipase from Acinetobacter johnsonii LP28 Suitable for detergent formulation. Fd. Technol. Biotechnol., 49: 96-102.

Watson, G.W. and Kubiriba, J., 2005. Identification of mealybugs (Hemiptera: Pseudococcidae) on banana and plantain in Africa. Afr. Entomol., 13: 35-47.

Weisberg, W.G., Barns, S.M., Pelleter, D.A. and Lane, D.J., 1991. 16S ribosomal DNA amplification for phylogenetic study. J. Bact., 173: 697-703. https:// doi.org/10.1128/JB.173.2.697-703.1991 